DOI 10.31558/2519-2949.2021.3.15

УДК 338.43:504.64

ORCID ID: https://orcid.org/0000-0002-0295-5332

Хилько М. І., Кийвський національний університет імені Тараса Шевченка

\title{
ЦІННОСТІ ЕКОЛОГІЧНОЇ БЕЗПЕКИ ЯК СОЦІОКУЛЬТУРНІ РЕГУЛЯТОРИ СОЦІМУ
}

Проаналізовано місие і роль иінностей екологічної безпеки в процесі изивілізаиійного розвитку. 3 'ясован, щоо значне погіршення якості життя має окреслений екологічний контекст, оскільки людство не завжди в змозі контролювати ті сили і технології, які воно створило, щьо і призвело до глобального апокаліпсису, що є свідченням вичерпності можливостей саморегуляції біосфери в умовах постійного зростання інтенсивності людської діяльності в природі.

Досліджено, щуо глобальна екологічна криза є наслідком дії багатьох чинників. Це $i$ споживацький підхід до природи, і природоруйнівний тип індустріального розвитку, і нерегульоване зростання народонаселення, i некомпетентність відповідних служб тощо. Однак є ще одна $i$, певно, найсуттєвіша причина екологічної кризи - глобальне падіння духовності і моральності, низький рівень екологічної освіти, екологічної культури загалом переважної частини мешканців планети. I так, на жаль, було завжди. Однак, останні десятиліття відзначаються особливим цинізмом: сплеск колективного егоїзму, нігілізму, локальних і регіональних збурень у суспільствах, планетарна епідемія аморальності, злочинності, алкоголізму, наркоманії, проституиії, тотальної легковажності, бездумності йжадоби швидкої наживи, індивідуальна деградація в різних проявах, ріст корупиї, некомпетентності при вирішенні людино-природних проблем.

Підсумовується, що ступінь суспільного поступу і иивілізованості не може вимірюватися лише кількісними показниками виробленого, а насамперед станом здоров'я людини, низкою моральних $i$ духовних критеріїв. Отже, людство мусить переглянути свої моральні парадигми, щяо призвели до деградації екологічної свідомості і знову відчути себе невід 'ємною часткою природи. Тільки глибокий переворот у свідомості людей, визнання природного довкілля як неперехідної життєстверджуючої цінністі може забезпечити екологічно безпечне середовище проживання $i$ врятувати иивілізачію від подальшої руйнаиії.

Ключові слова: цінності екологічної безпеки, екологічна криза, екологічна освіта, екологічна свідомість, иивілізація.

Сутністною ознакою глобальної екологічної кризи є порушення екологічної рівноваги і втрата природою властивості до саморегулювання і самовідновлення, як наслідок нестримної виробничої діяльності і споживацького, варварського ставлення до природи з боку суспільства. Отже доля майбутнього Цивілізації залежить від узгодженості людино-природних відносин, узгодженості економіки й екології. I навіть більше того, мову треба вже вести про зміну моральних парадигм людства, про заміну самого вектора розвитку, де основною є парадигма: «економічним є лише те, що $\epsilon$ екологічним».

Стає все більше вочевидь, що значне погіршення рівня і якості життя має окреслений екологічний контекст. Природа сама по собі вже не в змозі нейтралізувати результати господарсько-економічної діяльності людини і суспільства. Ставши «геологічною силою» [1, с.328], людство підкорило такі явища, які, вийшовши з-під його контролю, можуть покласти початок знищенню всього живого. Виявилося, що людство не завжди в змозі спрямовувати у потрібне русло сили, які воно породжує, i належним чином контролювати процес цивілізованого суспільного розвитку. До того ж, негативні зміни, що накопичуються в природі, за багатьма найважливішими параметрами дедалі більше наближуються до критичної позначки. Отже, часові межі вирішення проблеми екологічної кризи жорстко детерміновані.

Складається враження, що ніби все людство стало подобою чужеродної для земної природи сили. Немов закинуто десант космічних приблуд - ненажерливих споживачів матеріальних благ, готових знищити все довкола і помандрувати далі. Парадокс у тому, що головною і по суті єдиною руйнівною 
силою в природі є людина, homo sapiens, що поводиться далеко не як людина розумна, адже жодна тварина, жодний найпростіший організм у природі не знищує середовище свого помешкання так безжалісно, так бездумно, так послідовно і так масштабно, як людина. Навіть найпростіший мікроб запрограмований на екологічне самозабезпечення, саморегуляцію і відновлення середовища проживання. І лище людина займається самознищенням. Певно ніколи людина не буда так немилосердна до природи i до самої себе, як нині. Вона уподібнилася раковій пухлині, яка виникає в організмі, харчується і зростає за рахунок його, поступово знищуючи організм i, як наслідок, саму себе.

Певно, це і $є$ свідченням того, що найстрашнішим злом для природного довкілля $є$ забруднення людської свідомості хибними, чисто споживацькими, а то і злочинними ідеями. Саме тому, незважаючи на актуалізацію останнім часом природоохоронних проблем i визнання їх пріоритетними, людство до сьогодні перебуває у полоні технократичних ілюзій. Разом з тим, загроза глобального апокаліпсису свідчить про вичерпність можливостей саморегуляції біосфери в умовах зростання інтенсивності людської діяльності у природі. Функцію регулятора має відтепер виконувати суспільство. Ефективним засобом такого регулювання має бути зважена і науково обгрунтована соціально-екологічна політика. Людина як єдиний представник світу живого, що володіє розумом та свідомістю, несе відповідальність за збереження оптимальних умов свого подальшого існування. Настав час історично зворотнього: переведення людини із статусу «царя природи» в «громадянина природи» [2 с.124-126].

I світове товариство нарешті-то, хоч із значним запізненням, усвідомівши реалії, починає реагувати на реальну екологічну небезпеку. Так, у Хартії європейської безпеки (Стамбул, 1999 р.) деградація природного середовища визначена як новий загальний виклик і віднесена до серйозних факторів, що впливають на європейську безпеку [3]. Необхідність своєчасного розв'язання глобальних проблем для розвитку цивілізації підтверджено на Всесвітніх форумах (Ріо-де-Жанейро, 1992 р., Йоганнесбурзі, 2002 р.), ряді пан-європейських конференцій «Довкілля для Європи». I залежно від того, якою буде відповідь цивілізованого людства на цей виклик, залежить як безпека XXI століття так і ймовірність виживання самого людського роду.

«Необхідність пошуку шляхів виходу з глобальної екологічної кризи і розв’язання екологічних проблем, що виникли перед людством, вимагає істотну переорієнтацію економічних, політичних, соціальних, науково-технічних парадигм, що спрямовані на досягнення утилітарних, прагматичних, споживацьких цілей, на цінності екологічної безпеки, як духовні і соціально-культурні регулятори соціуму» [4, с.134]. Інакше - вже зараз може розпочатися стрімке руйнування цивілізації, тож треба рішитися хоч і на болісний, але урівноважений шлях переходу на нові пріоритети і принципи організації своєї життєдіяльності на основі реальної, а не декларативної гармонії усередині соціумів, між ними і Природою. Пошук і реалізація дійсного механізму цієї гармонізації, запровадження відповідних норм життєдіяльності в суспільну свідомість і підсвідомість Людства є надією на порятунок від загрози глобальної катастрофи (за даними Європейського центру нових технологій управління ризиками катастроф, кількість природних і техногенних катаклізмів у різних куточках планети у середньому зростає щороку на п'ять - сім відсотків).

Важливість дослідження ціннісних основ екологічної безпеки обумовлюється як необхідністю практичного вирішення проблеми збереження природних умов існування людства, так і соціальною потребою у створенні ефективного соціокультурного механізму регуляції відносин на екологічних принципах. Фактором, який посилює важливість проблеми для українського суспільства, виступає соціальна і духовна потреба у формуванні ціннісних основ екологічної свідомості як соціокультурних підвалин екологічної безпеки в умовах загострення екологічної кризи як в наслідок Чорнобильської катастрофи, так пожеж і вибухів на складах боєприпасів, ряду техногенних аварій в промисловості, знищенням біорізноманітності тощо.

Достеменно відомо, що наша планета задовго до появи людства піддавалася глобальним екологічним катастрофам, внаслідок яких зникло багато видів флори і фауни. Здебільшого екологічні негаразди минулого були пов'язані з дією стихійних природних чинників, сучасна ж екологічна криза, що виникла в другій половині XX ст., спричинена антропогенними чинниками, тобто внаслідок свідомого, цілеспрямованого i необмеженого зростання масштабів виробничої діяльності, виснаження і забруднення природного середовища, осмислюється науковим світом як загроза руйнування природних систем життєзабезпечення i саморегуляції біопроцесів Планети. Її характерними рисами є: порушення процесів самовідновлення атмосфери, гідросфери, літосфери і біосфери. Свідченням цього є руйнування озонового шару, критичне забруднення середовища помешкання, катастрофічне виснаження природних ресурсів, зміна енергетичного балансу планети 
(клімату), випадання кислотних дощів, опустелювання, водний голод, розширення епідемічних захворювань і взагалі загроза руйнування геному людини, ставлять людство на грань виживання i актуалізують проблему екологічної безпеки.

Безперечно, екологічні загрози супроводжували людство з часу його виникнення, однак усвідомлення значимості екологічної безпеки і потреби в ній відбулося набагато пізніше.

Так, для міфологічної свідомості людини було характерним одушевлення й обожнювання сил природи, що ототожнювалась з материнським початком, прагненням до пошуку гармонічного співіснування з природою. Природа розглядалася як вища цінність і умова для життя людини, а безпека існування племені і роду ставилася в залежність від дотримання етичних норм взаємин із Природою та іiі божествами. Епічні оповідання того часу в образно-символічній формі відображають боротьбу хаосу і космосу, стихії і порядку та інтерпретуються дослідниками як футурологічне відображення розвитку глобальної кризи у взаєминах природи і суспільства.

У період формування націй $\mathrm{i}$ національних релігій усвідомості людини відбувається трансформація поглядів на природу й ії ціннісний зміст, переосмислення причин екологічних загроз i умов безпечного існування етносів. Екологічні лиха і катастрофи: повені, пожежі, виверження вулканів, посуха, епідемії й ін. розглядаються як наслідок порушень встановлених Богом законів, результат розриву угоди між Богом і людьми. Християнство, як система світогляду і ціннісних орієнтирів, закликало до регулювання взаємини суспільства і природи на основі християнської етики, зорієнтованої на досягнення універсального принципу любові i, зокрема, любові до природи як до божого творіння. Іншою важливою складовою християнського світогляду і способу життя $є$ властивий, саме йому, принцип обмеження споживання, який використовується у духовно-аскетичній практиці. Екологічні нещастя і катаклізми трактуються з позицій теоретиків богослов'я і теології як покарання Богом людства за порушення Закону.

Разом $з$ тим, слід утриматись від ідеалізації християнського відношення до природи. У середні віки християнська теологія порушила античну гармонію мікро- і макрокосмосу, протиставила людину як найвище творіння Бога іншим менш досконалим продуктам творіння. Замість космічного Всесвіту античних мислителів, головним об'єктом дослідження стає людина, іï внутрішній світ, а формою соціального спілкування - церква. Християнство звільнило людину від світоглядно зумовленої боязні природи і надало їй підстави вважати себе володарем природи, що сама природа віддана в іі розпорядження Богом. Християнство дало можливість людині протиставити себе природі і навіть домінувати над нею. Так, зокрема Іісус Навін зупиняє Сонце; пророк Ісайя змушує його рухатись назад; а Мойсей повелівав і повітрю, і морю, і землі, і камінню. Про санкціоноване Богом панування людини над природою свідчить і теза із Книги Буття: 1.28: «І благословив їх Бог, промовляючи: ростіть і множтесь, i наповнюйте землю, і володійте нею, і володарюйте рибами морськими і звірами, i птахами, і всіма худобами, і всією землею». Що це як не санкція на підкорення природи. Разом з тим, за біблейською версією планета дана людям по милості Бога, в тому слід дотримуватись і його вимоги щодо дбайливого ведення господарства на Землі. Таке двоїсте ставлення до природи витікає із визначальної риси християнської релігії - протиставлення духа людини іiї тілу (плоті).

Однак, така двоїстість середньовічного світосприйняття, як не дивно, характеризувалась i відносною цілісністю, яка увібрала в себе вічне і тимчасове, божественне і земне, душу і тіло, церковне і мирське. Певно нема такої другої монотеістичної релігії окрім християнства, догматики якої з такою рішучістю відводили б людині центральне місце. Якщо бог якось-то став людиною, то в історії суспільної свідомості робиться зворотній висновок: людина, мовляв, може і повинна перетворитись на Бога. Підміна Бога людиною стала досить поширеною і в філософії Нової доби. Це позначилось на ставленні людини до природи, яке ставало дедалі агресивно-прагматичнішим, усе частіше створюючи непередбачувані труднощі, що негативно впливало на розвиток суспільства і природне середовище [5, с.172].

Просвітницька доба розпочалась з рішучого заперечення схоластики і відродження античної науки. Відбувається переосмислення відношення до природи, iї ролі в долі людства на основі антропоцентричних цінностей. Природа рефлексується у творчості мислителів цього періоду як еталон краси, єства і гармонії, як цінність, вище якої може бути тільки сама людина. Разом 3 тим, розвиток науки Нової доби формує раціоналістичні тенденції в поглядах на співвідношення природи і суспільства. Теоретично влаштовується не тільки діяльність людства з метою підпорядкування сил природи, але і їі експлуатація в інтересах суспільного прогресу. Технічні нововведення, поглиблення розподілу праці, відкриття і застосування нових джерел сировини та енергії, нові географічні та інші відкриття стимулювали розвиток природничих фундаментальних наук, таких як механіка, 
математика, астрономія, хімія, біологія. Водночас, диференціація наук і пошукових досліджень призвела до фрагментарного, однобічного (предметного) дослідження природи.

Часом не накові знання визначали процес природокористування, а скоріше навпаки, останній зумовлював напрямки наукових досліджень, на цьому грунті, власне, і виник союз спекулятивної та емпіричної науки, що й спричинив у подальшому екологічну кризу. 3 переносом виробничого акценту з землеробства на ремесла, а потім i на мануфактуру - природні цикли пір року поступаються місцем виробничим циклам. Саме звідси бере тенденція розглядати буття суспільства i буття природи як відособлені і незалежні процеси. Навколишнє середовище набуває статусу чинника, що протистоїть людині, який потрібно підкорити і перетворити на об'єкт технічного впливу, на невичерпне джерело ресурсів. Поступово, внаслідок розвитку продуктивних сил, людина сама перетворилась в джерело робочої сили, а природа - в небачене досі за своїми масштабами джерело сировини (Й. Фіхте, О. Конт).

Однак, саме в цей період у теоретичній і соціально-політичній думці відбувається зародження ідеї-припущення про «помсту» природи за зневагу до іiі законів і необхідності переоцінки відношення до природи як основи людського буття, що виразилося в гаслі Ж. Руссо «назад до природи» [6, с.89]. I все ж, орієнтація на підкорення природи, в міру зростання технічних можливостей людини (індустріальна доба) ставала домінуючою, що є свідченням екологічного відчудження людини як вияв іiї соціального відчудження. У значній мірі - це криза людського духу, свідомості, культури. Протягом віків людина руйнувала природне середовище спочатку у своїй свідомості, в процесі пізнання природи, а потім - матеріально, в процесі виробничої діяльності. Складається враження, що прагнення до руйнації і прагнення до підкорення природи є однією з визначальних рис природи самої людини, людини-самогубця. В сучасних же умовах людина розвинула такі продуктивні сили, відкрила такі технології, які вийдучи з під ії контролю покладуть початок загальному омніциду знищенням всього живого. Саме трагізм, небезпека глобального омніциду змушує людство шукати дороги до вживання, до порятунку. Тому глибинним призначенням екологічної політики є сприяння подоланню цих важких недугів [2, с.193-198].

Своєрідною спробою філософсько-культурного подолання технократичного способу відношення людини до природи й утвердження нової парадигми світоорієнтації, спрямованої на виживання людства, виявились роботи В. Вернадського, який спробував вибудувати нову теоретичну модель взаємодії людини з природним оточенням. Його вчення про ноосферу - як поглиблення і продовження концепцій П. Тейяр де Шардена - суттєво змінювало орієнтири практично-виробничої діяльності людини. Обрунтована В. Вернадським вимога розумної організації взаємодії суспільства і природи на противагу стихійному, хижацькому ії використанню, безпосередньо виводила вчених на гармонізацію взаємовідносин людини і природи [1]. На жаль і сьогодні його концепція до сих пір залишається поза запитом технократичного спрямованого мислення переважної частини населення світу.

I все ж, десь з середини 80-х років минулого століття розпочався процес більш реалістичного осмислення ролі науки і техніки в житті людини і суспільства. Посиленій увазі були піддані роботи західних фахівців. Філософськи розвідки все біль рішуче відмежовувались від ідеології. 3'явилась серія публікацій, в яких екологічна проблематика поступово підносилась до рівня ключової як в осмисленні перспектив розвитку локальних соціумів (культур, народів, держав), так і у визначенні можливостей виживання людства як цивілізації.

Безперечно, лідером докорінного переосмислення й усвідомлення катастрофічності екологічної ситуації, що прийняла глобальний характер, було здійснено вченими Римського клубу, який гостро поставив проблеми глобальної екологічної кризи і подальшого розвитку людства на «порядок денний». На переконання його засновника А. Печчеї, вирішення проблеми екологічної безпеки можливо лише за допомогою духовного відновлення людини, перебудови його свідомості і поведінки на основі революційного переосмислення пануючої системи цінностей та ідеалів.

Значною подією, що ознаменувала осмислення екологічної безпеки як глобального сутнісного фактора людського буття, можна вважати цикл публікацій (доповідей) Римського клубу. Не можна не помітити, що в перших доповідях клубу провідна роль відводилась науково-технічним аспектам екологічних проблем, що досить виразно відображено в праці групи М. Медоуза «Межі зростання» (Рим, 1972), то в наступних доповідях - «Людство на поворотному рубежі» М. Месаровича i Е. Пестеля (Нью-Йорк, 1974); «Перегляд міжнародного порядку» Я. Тінбергена (Роттердам, 1975); модель «Глобальні обмеження і новий погляд на розвиток», розроблена групою японських вчених під керівництвом I. Кайя; латиноамериканська модель дослідження шляхів вирішення глобальних 
проблем країнами, що розвиваються, створена під керівництвом А. Еррери; модель «Цілі глобального розвитку» (керівник Е. Лассо), в якій відображено необхідність перебудови системи цілей і оріентирів соціального прогресу; розробка Д. Габора з ін. «За межами епохи марнотрацтва» (Мілан, 1976); А. Пестеля «За межами зростання» (Москва, 1988); А. Печчеі «Людські властивості» (Москва, 1980); нарешті, доповідь І. Боткіна та ін. «Нема меж навчанню» (Нью-Йорк, 1979) і праця А. Гора «Земля у рівновазі. Екологія і людський дух» (Нью-Йорк, 1993) та ін. - суттєве місце приділяється соціальним і культурним передумовам пом'ягшення екологічної ситуації.

У доповідях зазначається, що глобалізація екологічної кризи залишає людству обмежений тимчасовий інтервал на вирішення проблеми його виживання. Ключем вирішення якого може бути нова парадигма соціального розвитку, що заснована на пріоритетах і цінностях екологічної безпеки на особистому, національному, регіональному і глобальному рівнях.

Зазначені глобальні моделі допомогли сприйняттю екологічних проблем як першочергових i, безперечно, стимулювати розвиток як неформального «зеленого руху», так і створенню відповідних державних (міністерств, агенств по охороні природи ) і міжнародних (ЮНЕСКО, ЮНЕП) органів і організацій на які покладено регулювання діяльності в галузі природокористування. I вже в 70-х роках $\mathrm{OOH}$ переходить до комплексного багатостороннього природоохоронного співробітництва. Це увінчалось прийняттям у 1972 p. на Першій всесвітній конференції по навколишньому середовищу міжнародних природоохоронних принципів (Стокгольмська декларація) і створенням спеціального органу - Програми ООН по навколишньому середовищу (ЮНЕП). У 1983 р. ООН створила Всесвітню Комісію по навколишньому середовищу і розвитку, якою було розроблено і затверджено Генеральною Асамблею ООН у 1987 р. «Всесвітню стратегію охорони природи». У важливому звіті цієї Комісії «Наше спільне майбутнє» пролунало попередження про те що людство повинно змінити багато чого у своїй діловій активності і способі життя, бо інакше його чекають тяжкі випробування і різке погіршення навколишнього середовища. Економіка повинна задовольняти потреби і законні бажання людей, але іiі зростання повинно вписуватись у межі екологічних можливостей планети. Комісія, названа по прізвищу свого голови Комісією Брундтланд (прем'єр-міністр Норвегії) закликала до «нової ери економічного розвитку, безпечного для навколишнього середовища». Вона заявила: «Людство в змозі зробити розвиток сталим - забезпечити, щоб воно задовольняло потреби теперішнього часу, не піддаючи ризику здатність майбутніх поколінь задовольняти свої потреби». Саме так вперше в міжнародних документах було використано термін «Sustainable development», який в українському перекладі інтерпретується як «сталий розвиток» [7].

Глибоке теоретичне обгрунтування ідеї сталого розвитку суспільства, іiі фундаментальна розробка в системі екологічних, політичних, соціальних та інших теоретичних знань, з врахуванням інтеграції зусиль усього світового співтовариства, на думку В. Горлинського, створює умови для формування на ії основі соціально-політичного ідеалу і перспективної соціальної мети. Разом з тим, ідея лише тоді втілюється в ідеал, коли опановує свідомістю суспільства як складова ідеологічна частина соціально-політичних програм. Переконаність у перспективі, істинності і доцільності ідеї $€$ умовою іiі метаморфози в ідеал- основну інтегровану форму функціонування цінностей. Ідеал виражає генеральну спрямованість діяльності особистості і суспільства. Соціальний ідеал сталого розвитку громадянського суспільства акумулює в собі сукупну ціннісну характеристику соціуму як зразок, і тому може виконувати функцію соціального стратегічного орієнтира. Досягнення цієї мети суспільством передбачає його орієнтацію на сукупність відповідних цінностей як проміжних соціально-політичних і духовних орієнтирів.

Сама ж констатація глобальної екологічної кризи й усвідомлення суспільством необхідності адекватних засобів, спрямованих на запобігання екологічної катастрофи, утвердилися провідними чинниками осмислення феномена екологічної безпеки як однієї з пріоритетних цінностей глобалізованого суспільства. У системі цінностей такого суспільства екологічна безпека виступає як пріоритетна цінність вищого порядку - суспільний ідеал. Аналіз екологічної безпеки як ціннісного феномена, на думку В. Горлинського, припускає виявлення двох сторін - предметної (явища екологічної безпеки як об'єкту ціннісного ставлення) і суб'єктної (результатів і способів ії̈ ціннісної рефлексії з боку суспільства) [4, с.139-140].

Узагальнюючи різні підходи до смислового наповнення поняття екологічної безпеки, В. Горлинський дає наступне їх трактування. Це:

- стан природних механізмів життєзабезпечення людства всіма необхідними первинними засобами існування: повітрям, теплом, питною водою, природними джерелами харчових продуктів, природними умовами трудової діяльності, відпочинку, культурного розвитку; 
- міра відповідності екологічних умов задачам збереження здоров'я людей і забезпечення сталого, узгодженого соціально-економічного розвитку, гармонізації інтересів природи і суспільства;

- збалансована взаємодія природи, технічних і соціальних систем, формування природнокультурного середовища, що відповідає санітарно-пгієнічним, естетичним і матеріальним потребам мешканців при збереженні природно-ресурсного й екологічного потенціалу природних систем і здатності біосфери до саморегулювання,

- системи правових норм і відповідних інститутів безпеки. що гарантують захист середовища проживання людини і суспільства;

- здатність управління екологічними ризиками [4, с.140-141].

Заслуговує на увагу і узагальнююче визначення вченим екологічної безпеки. «Екологічна безпека це стан сталої i динамічної рівновагі функціонування системи «природа-суспільство», що характеризується, з одного боку, захищеністю природного середовища від руйнівного антропогенного впливу i здатністю до самовідтворення екосистем, з іншого,- захищеністю суспільства від екологічних загроз і стихійних лих, забезпеченням здорових природних умов його життєдіяльності» [4, с.141].

Отже, сутнісний смисл екологічної безпеки полягає в збереженні життя як основи і єдиної форми буття живої природи й існування людського роду, що дозволяє судити про екологічну безпеку як про цінність вищого порядку. Врешті-решт у правовому полі цивілізованого людства цей принцип відображає головне природне право людини - право на життя [4, с.141].

Безперечно, екологічні труднощі значною мірою зумовлені пануючими в наш час системами цінностей. Кризові моменти у взаємовідносинах людини 3 навколишнім природним середовищем виникають, як це не парадоксально, з посиленням технічної могутності людини. І взагалі, суспільство проектує на природу свої як позитивні, так і негативні сторони і тим самим багато в чому визначає стан природи, що перетворюється. Сучасна екологічна криза - певною мірою симптом душевного i духовного неблагополуччя людини.

Що це так видно, хоча б, з такого прикладу. Переважна більшість людей ходить у ліс не для того, щоб слухати спів птахів і милуватися квітами, а по ягоди, гриби, на полювання. Можуть заперечити, що це, мовляв, потрібно, оскільки існують труднощі з продуктами харчування. Але таке пояснення далеко недостатнє, адже споживацтво поширене і в суспільстві, де продуктів вистачає. У принципі, скільки б людина не мала, вона завжди може хотіти більше.

Які екологічні наслідки цього? По-перше, орієнтація на споживацтво призводить до виснаження і деградації природи. I, по-друге, посилюється агресивність поведінки людини в умовах обмежених ресурсів. Споживацтво небезпечне і з економічної точки зору, оскільки природа не в змозі через обмеженість їі ресурсів у кожний даний момент часу задовольнити нескінченні матеріальні потреби людини. Крім того, націлена на споживацтво так званих модних, престижних речей людина втрачає розуміння цілісності природи, цілісність ставлення до неї і слідом за тим цілісність самої себе як особистості. Для неї чистота повітря, води, грунтів і лісів перестає бути цінністю. Головне - достаток, гроші та інші подібні приваби. У цьому сенс примітивного споживацького підходу до життя і природи.

Тож необхідно змінити цінності, насамперед ті, які регулюють ставлення людини до природи. Важливо усвідомити, що саме по собі зростання добробуту, поліпшення умов існування ще не робить людей щасливими. І потрібно вгамувати свої традиційні раціонально-прагматичні пріоритети, суттєво підвищити рівень моральності й духовності. Стратегія практичних орієнтацій людства має суттєво змінитися, адже в процессі природокористування здобувається не тільки «хліб насущий», а й «хліб духовний». Природу не можна сприймати як комору, з якої людина бере в необмеженій кількості те, що їй потрібно, а повертає відходи своєї діяльності, до яких їй немає ніякого діла. Природа, звичайно, не храм, яким належить захоплюватись, але і не тільки майстерня, а джерело фізичного і духовного життя людини, неминуща цінність, що має для людського існування вирішальне значення.

На жаль, людина змушена була боротися з природою і приречена на боротьбу при всіх можливих способах виробництва. Тобто, єдність людини і природи досить суперечлива. Але це не означає, що цю суперечливість потрібно загострювати i надалі, наближаючи екологічну катастрофу i сподіваючись, що людина зможе адаптуватись до будь-яких змін. Боротьба з природою, очевидно, ніколи не скінчиться, але перемога над нею обертається для людини поразкою, оскільки сама людина - частина природи, а природа - початок, що породжує іiі.

Слід зауважити, що значне число жителів планети були «мічуринцями» і жили за принципом: «Ми не можемо чекати милостей від природи, взяти їх у неї - наше завдання». Взяти милість силою? 
Але ж саме прагнення якомога більше взяти і призвело до того, що нині дійсно вже не слід чекати милості від природи, адже ми в неї вже і так забагато взяли.

Людина віками і пристосовувалась і вела боротьбу зі стихійними силами природи. I ось нарешті вона вперше може іiі знищити. Вже знищивши багато представників флори і фауни на Землі, людина переступила ту межу, за якою руйнуються основи існування активної частини природної системи в цілому та іiі окремих частин зокрема. Саме тому головним «стихійним лихом» $\mathrm{i}$ для природи $\mathrm{i}$ для людини стає вона саме. Споживач має стримувати себе, не забувати, що не можна постійно брати, не віддаючи, інакше звідки візьметься бажане? Загалом, $\epsilon$ всі підстави стверджувати, що обмеженість сучасного людства в ресурсах - це результат дії певних соціальних і культурних чинників, на які можна певною мірою впливати через організацію суспільного життя. Вищі духовні цінності повинні якось регулювати побутові потреби та їх диференціацію. Потрібне нове переосмислення місця людини у світобудові: розглядати людину не як завойовника природи, а як органічну іiі складову частину [2, с.126-128]. Ідея всеосяжного контролю над природою $€$ «плодом зарозумілості, що, - як стверджує Р. Карсон, - і народилася тоді коли біологія та філософія перебували на неандертальському рівні і коли вважалося, що природа існує лише для комфорту людини» [8, с.27].

Разом з тим, відрадно заявити, що в Законі України «Про Основні засади (стратегію) державної екологічної політики України на період до 2030 року» в розділі ІІІ «Стратегічні цілі та завдання» на першому плані стоїть: «формування у суспільстві екологічних цінностей і засад сталого споживання та виробництва», а серед завдань зокрема наступні:

- впровадження освіти в інтересах збалансованого (сталого) розвитку, екологічної освіти та виховання, просвітницької діяльності з метою формування в суспільстві екологічних цінностей і підвищення його екологічної свідомості;

- оцінка ставлення та підвищення рівня поінформованості суспільства щодо значення, переваг та інструментів сталого споживання і виробництва, стану і цінностей біорізноманіття та заходів, які необхідно здійснити для його збереження, відновлення і сталого використання;

- забезпечення практичної реалізації результатів сучасних та фундаментальних екологічних досліджень та безперервної взаємодії між науковцями та державними органами;

- врахування рекомендацій наукових установ екологічного спрямування при прийнятті управлінських рішень та підготовці проектів нормативно-правових актів;

- розвиток партнерства між секторами суспільства з метою залучення до планування і реалізації природоохоронної політики усіх заінтересованих сторін;

- забезпечення участі громадськості у прийнятті управлінських рішень усфері охорони навколишнього природного середовища та природокористування;

- забезпечення дотримання екологічних прав та обов'язків громадян, доступу громадськості до правосуддя з питань охорони навколишнього природного середовища та природокористування [9].

Отже, Закон репрезентує цінності екологічної безпеки, надає нові можливості для виявлення чинників ризиків і загроз, що складуть канву для розробки і вирішення конкретних проблем екологічної безпеки. Однак реалізація ціннісних смислів екологічної безпеки буде залежати значною мірою від ефективності функціонування політичної, економічної, соціальної, духовної та інформаційної сфер суспільства.

\section{Бібліогафічний список:}

1. Вернадский В.И. Химическое строение биосферы Земли и ее окружения. Москва: Наука, 1965. 374 с.

2. Хилько М.І. Екологізація політики. Київ.: ВАДЕКС, 2014. 344 с.

3. Браун Л.Р. Виклик нового століття. Стан світу 2000. Інститут сталого розвитку; Пер. з анг. Київ: Інтелсфера, 2000. $327 \mathrm{c}$.

4. Горлинський В.В. Філософія безпеки і сталого людського розвитку: ціннісний вимір. Київ: Вид. ПАРАПАН, $2011.378 \mathrm{c}$.

5. Толстоухов А.В., Хилько М.І. Екобезпечний розвиток: пошуки стратегем. Київ: «Знання України», $2001.333 \mathrm{c}$.

6. Руссо Ж.Ж. Трактаты. Москва: Наука. 1969. 703 с.

7. Програма дій: Порядок денний на XXI століття; Пер. з анг.: ВГО «Україна. Порядок денний на XXI століття». Київ: Інтерсфера, 2000. 360 с.

8. Экологическая антология: Экологические произведения западных авторов / Сов.-амер. гуманитарная инициатива «Голубка»; Редкол.: Г. Уорнер и др. Москва-Бостон, 1992. 267 с.

9. Закон України «Про Основні засади (стратегію) державної екологічної політики України на період до 2030 р. № 2697-VIII від 28.02.2019 р. Відомості Верховної Ради. 2019 № 16 ст. 70. 


\section{Referenses:}

1. Vepnadskyi V.Y. Khymycheskoe stpoenye byosfepы Zemly y ee okpuzhenyia. Moskva: Nauka, 1965. $374 \mathrm{~s}$.

2. Khylko M.I. Ekolohizatsiia polityky. Kyiv.: VADEKS, 2014. 344 s.

3. Braun L.R. Vyklyk novoho stolittia. Stan svitu 2000. Instytut staloho rozvytku; Per. z anh. Kyiv: Intelsfera, 2000. $327 \mathrm{~s}$.

4. Hoplynskyi V.V. Filosofiia bezpeky i staloho liudskoho rozvytku: tsinnisnyi vymir. Kyiv: Vyd. PARAPAN, 2011. $378 \mathrm{~s}$.

5. Tolstoukhov A.V., Khylko M.I. Ekobezpechnyi rozvytok: poshuky stratehem. Kyiv: «Znannia Ukrainy», $2001.333 \mathrm{~s}$.

6. Russo Zh.Zh. Traktatы. Moskva: Nauka. 1969. $703 \mathrm{s.}$

7. Prohrama dii: Poriadok dennyi na KhKhI stolittia; Per. $\mathrm{z}$ anh.: VHO «Ukraina. Poriadok dennyi na KhKhI stolittia». Kyiv: Intersfera, 2000. $360 \mathrm{~s}$.

8. Эkolohycheskaia antolohyia: Эkolohycheskye proyzvedenyia zapadnukh avtorov / Sov.-amer. humanytarnaia ynytsyatyva «Holubka»; Redkol.: H. Uorner y dr. Moskva-Boston, 1992. $267 \mathrm{~s}$.

9. Zakon Ukrainy «Pro Osnovni zasady (stratehiiu) derzhavnoi ekolohichnoi polityky Ukrainy na period do 2030 r. № 2697-VIII vid 28.02.2019 r. Vidomosti Verkhovnoi Rady. 2019 № 16 st. 70.

\section{Khylko M. I. Values of Ecological Safety as Sociocultural Regulators of Society}

The place and role of values of ecological safety in the process of civilizational development are analyzed. It was found that a significant deterioration in quality of life has a defined environmental context, as humanity is not always able to control the forces and technologies it has created, which led to a global apocalypse, which is evidence of the exhaustion of self-regulation of the biosphere. activities in nature.

It has been studied that the global environmental crisis is the result of many factors. This is the consumer approach to nature, and the destructive type of industrial development, and unregulated population growth, and the incompetence of the relevant services and so on. However, there is another and probably the most significant cause of the ecological crisis - the global decline of spirituality and morality, low level of environmental education, environmental culture in general, the vast majority of the world's inhabitants. And so, unfortunately, it always was. However, recent decades have been marked by a special cynicism: a surge of collective selfishness, nihilism, local and regional unrest in societies, a planetary epidemic of immorality, crime, alcoholism, drug addiction, prostitution, total frivolity, thoughtlessness and greed for quick profit, individual degradation and degradation., incompetence in solving human-natural problems.

It is concluded that the degree of social progress and civilization can not be measured only by quantitative indicators of production, but primarily by the state of human health, a number of moral and spiritual criteria. Thus, humanity must reconsider its moral paradigms, which have led to the degradation of environmental consciousness, and once again feel an integral part of nature. Only a deep revolution in the minds of people, the recognition of the natural environment as an inalienable life-affirming value can provide an environmentally safe habitat and save civilization from further destruction.

Keywords: values of ecological safety, ecological crisis, ecological education, ecological consciousness, civilization. 